\title{
Case Report: \\ MANAGEMENT OF PROGRESSIVE LUNG CANCER PATIENTS AFTER FIRST-LINE EGFR TYROSINE KINASE INHIBITOR THERAPY
}

\author{
Sahrun, Laksmi Wulandari \\ Department of Pulmonology and Respiratory Medicine, Faculty of Medicine, Universitas Airlangga, Dr. Soetomo \\ Hospital, Surabaya, Indonesia
}

\section{ABSTRACT}

Various tyrosine kinase inhibitor (TKI) drugs have been widely used as therapy for cancer that has EGFR mutations, or abnormal EGFR activation. However, patients who have a mutation in the gene that activates EGFR only benefit from EGFRTKI therapy for less than one year, because after that resistance occurs. In the management of patients according to NCCN 2017, patients who experience progress after receiving TKI as the first-line therapy must undergo an examination to identify the presence of T790M mutation. If the T790M mutation is positive, the choice of therapy that needs to be provided is the third generation (Osimertinib). Many recent studies have proved the significance of the effectiveness and response of Osimertinib therapy in lung cancer with EGFR T790M mutation. We reported the management of a pulmonary adenocarcinoma patient with positive EGFR mutation who had received first-line EGFR TKI who had progressive disease and T790M mutation in Dr. Seotomo Hospital. The patient finally received Osimertinib through an Early Access Program with a therapeutic response that improved significantly.

Keywords: Tyrosine kinase inhibitor; TKI resistance; T790M mutation; progressive disease; osimertinib

\section{ABSTRAK}

Berbagai obat golongan tyrosine kinase inhibitor (TKI) telah banyak digunakan sebagai terapi kanker yang memiliki mutasi EGFR, atau aktifasi EGFR yang abnormal. Akan tetapi, pasien-pasien yang memiliki mutasi pada gen yang mengaktifasi EGFR hanya mendapat manfaat dari terapi EGFR-TKI selama kurang dari satu tahun, karena setelah itu terjadi resistensi. Dalam tatalaksana pasien menurut NCCN tahun 2017, pasien yang mengalami progress setelah pemberian TKI sebagai terapi lini pertama harus menjalani pemeriksaan untuk mengidentifikasi keberadaan mutasi T790M. Jika mutasi T790M didapatkan positif, pilihan terapi yang perlu diberikan adalah generasi ketiga (Osimertinib). Penelitian terbaru banyak yang membuktikan signifikansi efektivitas dan repons terapi Osimertinib pada kanker paru dengan mutasi EGFR T790M. Kami melaporkan tatalaksana seorang pasien adenokarsinoma paru dengan mutasi EGFR positif yang telah mendapatkan EGFR TKI lini pertama yang mengalami progressive disease dan mutasi T790M di Rumah Sakit Dr. Seotomo. Pasien akhirnya mendapatkan Osimertinib melalui Early Access Program dengan respon terapi yang membaik signifikan.

Kata kunci: Tyrosine kinase inhibitor; resistensi TKI; mutasi T790M; progressive disease; osimertinib

Correspondence: Laksmi Wulandari, Department of Pulmonology and Respiratory Medicine, Faculty of Medicine, Universitas Airlangga, Dr. Soetomo Hospital, Surabaya, Indonesia. E-mail:

pISSN:2355-8393 • eISSN: 2599-056x • doi: http://dx.doi.org/10.20473/fmi.v55i3.15509

• Fol Med Indones. 2019;55:239-245 • Received 21 Feb 2019 • Accepted 18 Jul 2019

- Open access under CC-BY-NC-SA license • Available at https://e-journal.unair.ac.id/FMI/

\section{INTRODUCTION}

Lung cancer is the highest cause of deaths due to cancer in the world, both in developed and developing countries (Jemal et al 2003). According to GLOBOCAN in 2008, lung cancer has also become the most diagnosed cancer case and the cause of death from cancer in ASEAN countries. This should be a special concern, because statistical data shows that lung cancer is a lethal disease with a low survival rate. Only $15 \%$ of patients diagnosed with lung cancer survive in the next 5 years (Mok et al 2009). Treatment of pulmonary tumor types of NSCLC (Non-Small Cell Lung Cancer) depends on the stage at the time of finding. For advanced stage (IIIB-IV) the choice of therapy is radiotherapy, chemotherapy or a combination of both (Rosell et al 2009). Radiotherapy is given as palliative therapy or symptom prevention (Category 2A NCCN). In advanced NSCLC, chemotherapy can be provided for treatment purposes if the patient's general performance 
is good (WHO Performance Score 0-2) (Sequist et al 2011).

First-line therapy is given to patients who have never received prior treatment. Second-line therapy is given to patients who have received first-line therapy, but did not respond after 3 cycles, or the cancer becomes progressive. According to the 2017 NCCN tumor therapy guidelines, cancers classified as adenocarcinoma, large cell, squamous cell carcinoma and other non-specific NSCLCs need to be subjected to molecular testing and determination of PD-L1 status to determine tumor genetic mutations. All patients who have been diagnosed with adenocarcinoma can be given first-line platinum-based chemotherapy from the start or after the results of the EGFR mutation are identified. Especially for adenocarcinoma, if the molecular test of EGFR mutation is found to be sensitive when the patient is undergoing chemotherapy, chemotherapy can still be continued to completion, or given as maintenance therapy, or target therapy can be directly provided. If the EGFR mutation has been identified from the beginning, then the EGFR TKI can immediately be the choice of first-line therapy. Conversely, if the EGFR mutation turns out to have a negative result, the choice of treatment is platinumbased chemotherapy. Furthermore, the progression of EGFR TKI is observed. If progress occurs due to T790M mutation, the next treatment option will be the administration of second-line EGFR TKI (Osimertinib) (Sequist et al 2011, Thomas et al 2004, WHO 2004).

There are several mechanisms for the occurrence of resistance to EGFR-TKI, such as secondary mutations (T790M), alternative path activation (c-Met, HGF, AXL), abnormalities at the end of the pathway (K-RAS mutation, loss of PTEN), EGFR-TKI-mediated disruption of apoptosis pathways (polymorphism in the form of BCL2-like 11/BIM gene deletions), histological changes, ATP binding cassette (ABC) transporter effusions, and others (Ettinger et al 2010, Parkin et al 2002).

Adenocarcinoma patients with EGFR mutation initially respond strongly to EGFR TKI therapy, but will subsequently experience secondary (acquired) resistance with a median Progression-Free Survival (PFS) of 9-14 months (Mok et al 2009, Sequist et al 2011). The AURA 3 trial, using cell-free DNA examination, found that around $51.2 \%$ of the patients had a positive T790M mutation. This is the reason of why $60 \%$ of patients who have received EGFR TKI eventually experience EGFR T790M mutation in exon 20, which has been investigated as being related to molecular change (Parkin et al 2002, Yang et al 2005). In this case report we discussed a pulmonary adenocarcinoma patient with a positive EGFR mutation who had received first-line
EGFR and experienced progressive disease and T790M mutation.

\section{CASE REPORT}

Mr. J, 54, worked as a handyman with a history of smoking 1 pack per day for 32 years, coming with complaints of coughing up blood. The complaint was also accompanied by coughing up thick white phlegm. The body was weak, appetite lost, and bodyweight decreases. Temperature was high, with intermittent short of breath.

CT-Scan Guiding FNAB in dextral pulmonary mass showed adenocarcinoma, and EGFR mutations examination revealed exon 19 positive. The patient began to receive targeted treatment therapy with Gefitinib $250 \mathrm{mg}$ tablets once daily for 7 months. Initially, the patient responded well to Gefitinib therapy as evidenced by improved clinical conditions, coughing and shortness decreases, appetite and weight increased. In the first three months the results of RECIST-based CT scan showed partial response. After Gefitinib therapy entered the 7th month, the results of CT scan showed that the patient's condition was worsening with progressive disease. The patient then received second line therapy with Docetaxel for 4 series. Post threecycle Docetaxel, thoracic CT-scan was evaluated and clinical progressive disease was deteriorated on RECIST, so that the patient was admitted to the hospital.

Physical examination showed that the mass in the right thoracic region was $8 \times 15 \mathrm{~cm}$, and collateral veins appeared. Edema was seen in both upper limbs and the one on the left was more severe. Subsequently, the patient underwent a liquid biopsy (CT-DNA) examination to assess the suspicion of secondary mutations due to exposure to first-line EGFR TKI. The results of EGFR CT-DNA examination showed positive mutations in exon 20 T790M.

The patient followed osimertinib early access program and start getting $80 \mathrm{mg}$ osimertinib every 24 hours orally. Clinical evaluation was carried out 5 days after $80 \mathrm{mg}$ osimertinib treatment, and significant improvement was found, coughing was reduced, congestion improved, appetite increased, and the edema of the limbs decreased considerably. Collateral venous ectasia started to decrease with a decrease in JVP. CXR evaluation showed a reduction in homogeneous opacity as much as $2 / 3$ of the right lung. The pulmonary parenchyma started to appear clearly again, accompanied by a decrease in right and left pleural effusion. Laboratory evaluation also showed improvement. 

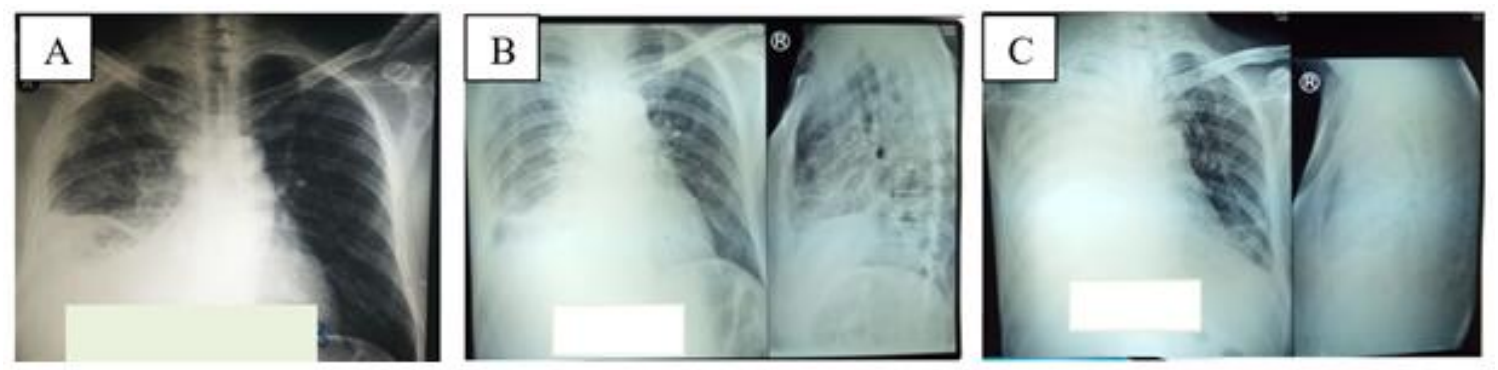

Fig. 1. (A) Chest X-ray of the patient at the beginning of a lung tumor diagnosis. The right costophrenic angle looks blunt. There is a homogeneous coating in $1 / 3$ of the lower right lung. (B) Chest X-ray of the patient after receiving Gefitinib $250 \mathrm{mg}$ target therapy for 3 months and experiencing a partial response. (C) The patient's chest X-ray at the time of admission to the emergency room, where homogeneous opacity appears to be wider and meet all right hemithorax.
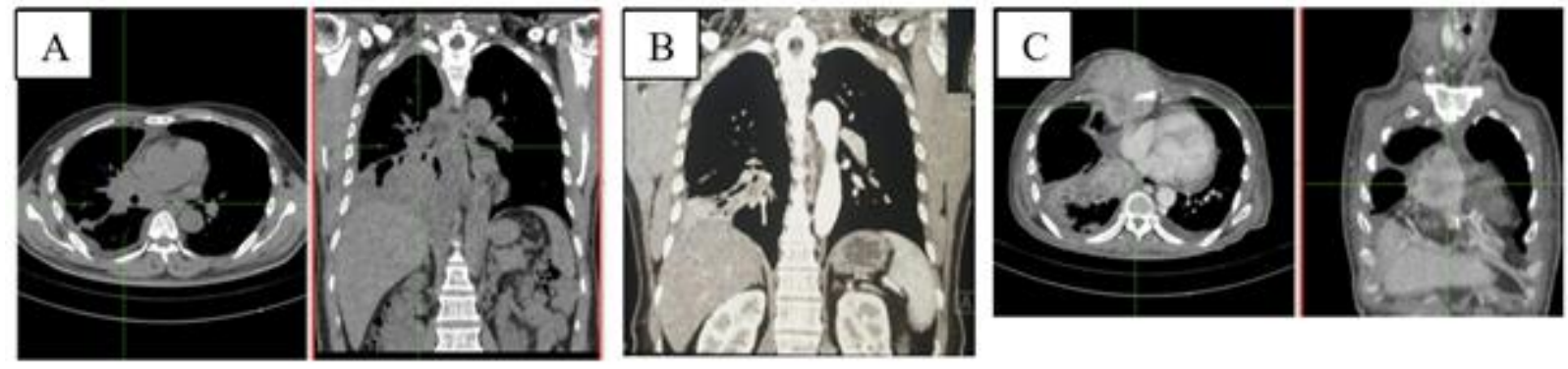

Fig. 2. (A) Initial CT-scan when the patient was diagnosed with a right lung tumor, there is a solid mass in the 8-9 segment measuring 3.56 x 3.61 x $5 \mathrm{~cm}$. Dextral costa IV nodules sized 3.69 × 5.32 x $4 \mathrm{~cm}$ is visible. Dextral pleural effusion is also visible. (B) Evaluation of thoracic CT scans after the patient has received Gefitinib 250 mg target therapy for the first 3 months. The size of the mass is relatively small (> 30\%). Right upper paratracheal lymph nodes, paraorta, lower paratracheal are detected. There is right pleural effusion, soft tissue mass bulging with corpus sternum destruction. RECIST criteria: Partial response. (C) The patient's thoracic CT scan at a follow-up evaluation when the patient experiences progression of the disease and finally is admitted to the hospital (indefinite lung mass border, irregular edges measuring 8.5 x 6, 5 x 9.9, cm on the right anterior hemithorax wall. The mass destroys the sternum and extending into the anterior mediastinum: It appears solid with a firm boundary, irregular edges measuring $2.3 \times 3.7 \times 4.0 \mathrm{~cm}$ posterior to the right hemitorax that erode the right posterior costa 2-4 and extends to the pleural cavity. The mass size of $2.5 \times 2 \times 6 \times 3 \mathrm{~cm}$ is seen in the right upper abdominal wall at the level of the liver. Fluid density appears in the right and left pleural cavity, RECIST criteria: Progressive disease).

After a 20-day first visit to the Oncology Clinic, Dr. Soetomo Hospital, the patient's family contacted the doctor and found the patient died when he woke up on the morning of December 17, 2017. The patient was suspected of dying from a pulmonary embolism from Deep Vein Thrombosis (DVT).

\section{DISCUSSION}

According to the $2017 \mathrm{NCCN}$, adenocarcinoma patients should be explored to see the presence of mutations to determine target therapy. If the molecular test results show a positive EGFR mutation, then the target therapy must be started immediately and its progressivity observed. The median survival rate after getting an
EGFR for TKI is 9-14 months. If there is a progress with the secondary T790M mutation, the choice of therapy is the administration of second-line TKI EGFR (Osimertinib) (Sequist et al 2011, David et al 2017, Thomas et al 2004). In this case report, the results of anatomical pathology examination in pulmonary adenocarcinoma patients showed positive EGFR mutations in exon 19. Patients were given firstgeneration TKI therapy Gefitinib $125 \mathrm{mg}$ daily orally for 7 months. Initially the patient experienced a fairly good treatment response with the results of the thoracic CT-scan evaluation with the RECIST partial response criteria. But in the seventh month the first-line EGFR TKI treatment patients progressed until finally the patient was hospitalized. 

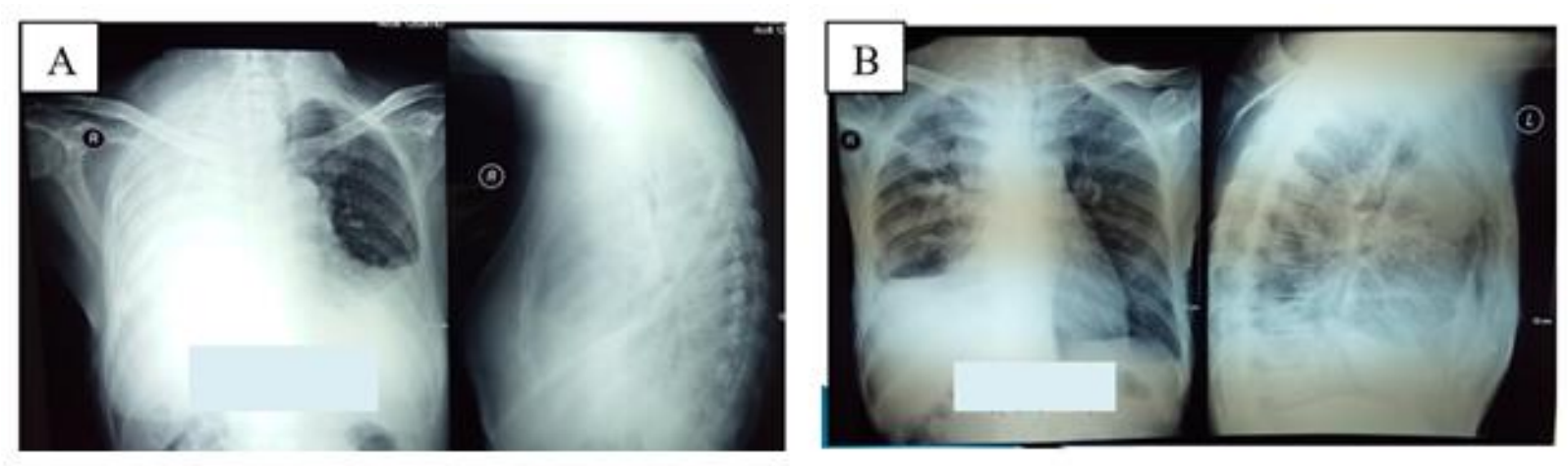

Fig. 3. (A) Chest X-ray of the patient at the beginning of admission before getting second-line radiotherapy and EGFR. Homogeneous opacity appears to fill the entire right lung field, obstructing the appearance of pulmonary parenchyma. The left costophrenic angle also looks blunt. (B) Chest X-ray of the patient after obtaining 13-series radiotherapy and the second line EGFR TKI (osimertinib). During the visit complaints of shortness of breath, coughing, and chest pain were not found. Left hand swelling diminishes.

Medicines belonging to the tyrosine kinase (TKI) inhibitor have been widely used as cancer therapies that have an EGFR mutation or abnormal EGFR activation. Gefitinib can inhibit TK domains from EGFR reversibly by competing with ATP competitively. TKIs also cause tumor cell death through BCL2-like 11 (BIM) mediated apoptosis. However, patients who have a mutation in the gene that activates EGFR only benefit from EGFR-TKI therapy for less than 1 year, because after that resistance occurs. The etiology of resistance to EGFR-TKI is very complex. Based on cell signal transduction pathways, the etiology of EGR-TKI resistance can be divided into several categories (Yun et al 2008).

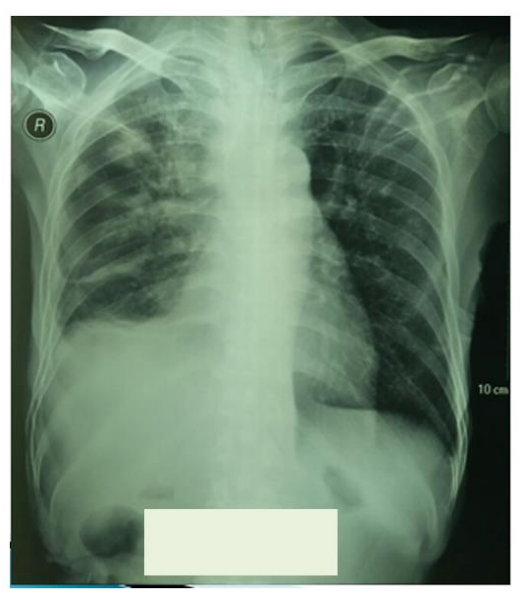

Fig. 4. Chest X-ray 21 days after osimertinib administration. The appearance of $2 / 3$ of the right lung is increasingly clear and the right-left costophrenic angle is sharp.
Initially, adenocarcinoma patients with EGFR mutations greatly respond to EGFR TKI therapy, but will subsequently experience secondary (acquired) resistance with median progression-free survival (PFS) averaging 9-14 months, even with a dramatic initial response. This means that every time a patient receives TKI, within an average period of 9-14 months he will experience progress related to various mutation pathways used by the tumor. The most common secondary mutation is T790M. It is evident that $60 \%$ of patients who have received EGFR TKI eventually experience EGFR T790M mutations in exon 20 which is believed to be related to molecular changes (Shinagare et al 2011, Carson et al 1992). Patients who experience progression after the administration of TKI can be identified clinically and radiologically. Evaluation of therapeutic response to chemotherapy is performed by obsverving changes in tumor size after the 3rd chemotherapy administration (cycle) (Greene et al 2002).

In these patients clinical deteriorations were in the form of shortness of breath and heavy coughing, heat, nausea, vomiting, coughing up blood, decreased appetite, decreased body weight, and edema of the legs as a sign of VCSS due to tumor crushing. In addition, there were signs of massive pleural effusion, filling the entire right lung field. Whereas, treatment response assessed from tumor radiological profile resulted from thoracic CT scans, showed that tumor mass increased of $>25 \%$ with RECIST criteria for of progressive disease.

Shortness of breath occurs because of the inflammatory process of the lower airways by infection and the 
presence of blockage on the right heart which interfere with circulation and right heart oxygenation so that it appears as a symptom of hypoxemia. Hemoptysis can occur due to the process of necrosis and inflammation of blood vessels in tumor tissue. Invasion of tumors into pulmonary blood vessels is rare. Hemoptysis can occur in $7-10 \%$ of patients with bronchogenic carcinoma (Kosasih et al 2008).

Vena cava superior syndrome (VCSS) is a collection of symptoms due to widening of the veins that carry blood from upper body part to the heart. Inhibition of blood flow (occlusis) that passes through this vein can cause superior vena cava syndrome (VCSS) (Arief 2009). More than $95 \%$ of all VCSS cases involve upper thoracic cancer, and the case that mostly associated with VCSS syndrome is lung cancer, which is close to $80 \%$ of all cases of superior vena cava syndrome and lymphoma (Brzezniak et al 2017).

In non-small-cell lung cancer patients who initially respond to EGFR TKI, there is resistance to EGFR inhibitors, which then results in treatment failure related to its development. Most studies found that the EGFR mutation occurred in exon 20, resulting in substitution of methionine for threonine in codon 790 (T790M) (Huang, Fu 2015). The AURA 3 trial, using cell-free DNA examination, found that around $51.2 \%$ of patients had positive T790M mutation. This mutation causes tridimensional changes in tyrosine kinase domain structure and prevents the binding of erlotinib and gefitinib to EGFR (Ciardiello, Tortora 2008).

According to the NCCN in 2017, patients who experience progress after receiving TKI as first-line therapy must undergo EGFR T790M mutation examination. If the results of the EGFR T790M mutation are obtained positively, then the treatment choice is second-line TKI (osimertinib). Conversely, if the results of EGFR T790M mutation are negative, then the therapy given can be in the form of chemotherapy.

Many recent studies have proved the effectiveness and therapy response of osimertinib which is quite significant for lung cancer with T790M mutation. Based on the Aura Study II, the effectiveness of osimertinib in controlling adenocarcinoma with the T790M mutation reached $91 \%(95 \% \mathrm{CI}, 88,94)$ and overall response rate (ORR) was $66 \%$ (95\% CI, 61, 71). Another study, the Apple Trial 2017, also revealed osimertinib's response to pulmonary adenocarcinoma with T790M mutation, which found a longer progression-free survival rate of up to 18 months until the end of treatment. The same study by TS Mok et al (2017) showed that in the third trial on osimertinib effects compared to platinumpemetrexed on EGFR T790M showed that free survival rate progression increased significantly to 10.1 months compared to platinum-pemetrexed which was only 4.4 months. In addition, ORR was also found to be quite significant at $71 \%(95 \% \mathrm{CI}, 65-76)$ when compared to platinum-pemetrexed, which was only $31 \%(95 \% \mathrm{CI}$, 24-40) (Mok et al 2009, Ciardiello, Tortora 2008, Socinski et al 2016).

After CT-DNA examination, the patient was found to have a mutation in the T790M. The patients should have been given with second-line TKI (osimertinib), but because the drug has not yet been available in Indonesia, the patient was temporarily given with second-line chemotherapy docetaxel as many as 4 series. The patient underwent 4 cycles of docetaxel chemotherapy until October 2017. Post 3-cycle docetaxel evaluation of chest CT-scan was carried out in September 2017 and RECIST criteria of progressive disease was obtained. The patient then followed osimertinib's early access program with a significant therapeutic response manifested as clinical and radiological improvements. The patient, who was initially congested, coughed, weak and had difficulty moving, experienced improvement within 5 days after the administration of osimertinib. Hematological markers and signs of VCSS also appeared to be improving. CXR evaluation was very clearky showing significant reduction in tumor mass and effusion, so that in the end the patient could continue the therapy on an outpatient basis.

During outpatient therapy, the patient did not complain of shortness and coughing, had improved appetite and weight gain was reported to increase. Before the second visit to the clinic, the patient was found dead at the time he should had woken up, without any prior complaints of shortness and coughing or fever. It was suspected that the patient died from pulmonary embolism originating from deep vein thrombosis (DVT). It is known that the incidence of thromboembolism is basically quite low in general population, but its incidence increases 4-7 times higher in cancer patients, depending on the type and stage of the tumor (Nordstrom et al 1992, Falanga 2009). An estimated $20 \%$ of all Venous Thromboembolism (VTE) is caused by cancer (Lee 2005). Pulmonary embolism and DVT are manifestations of VTE. Lung cancer is the most malignant disease associated with VTE. A recent study of case-control populations found that blood malignancies, followed by pulmonary and gastrointestinal malignancies, are the major causes of VTE (Sorensen et al 2000, Blom et al 2005). 


\section{CONCLUSION}

We have reported one case of a 54-year-old male patient with stage IV EGFR adenocarcinoma with exon 19 mutation and a secondary mutation in exon 20 T790M. Clinical manifestations in the patients are the presence of shortness, coughing, coughing up blood and signs of VCSS due to obstruction by tumor suppression on superior vena cava. The results of special examination on thoracic CT-scan showed a right lung tumor mass. Anatomic histopathology examination showed adenocarcinoma. Examination of EGFR mutations revealed exon 19 mutation, and CT-DNA examination showed a secondary mutation of T790M. Initially, the patient received EGFR-TKI gefitinib chemotherapy, showing partial response, then becoming progressive after 7 months. The patients then underwent second-line chemotherapy with docetaxel for 4 series, the response was poor and progressive. The patient finally received osimertinib with a significantly improved therapeutic response. Improvement evaluation, even after visit, again showed improvement in clinical and radiological conditions.

\section{REFERENCES}

Arief N (2009). Kegawatdaruratan paru, departemen pulmonologi dan ilmu kedokteran respirasi FKUI RS PERSAHABATAN, Universitas Indonesia

Blom JW, Doggen CJ, Osanto S, et al (2005). Malignancies, prothrombotic mutations, and the risk of venous thrombosis. JAMA 293, 715-722. Available at https://www.ncbi.nlm.nih. gov/pubmed/157019 13. Accessed September 13, 2018

Brzezniak C, Oronsky B, Carter CA, et al (2017). Superior vena cava syndrome in a patient with smallcell lung cancer: A case report. Case Rep Oncol 10, p 252-257

Carson JL, Kelley MA, Duff A, et al (1992). The clinical course of pulmonary embolism. N Engl J Med 326, p 1240-1245. Available at https://www.ncbi .nlm.nih.gov/pubmed/ 1560799. Accessed September 11,2018

Ciardiello F, Tortora G (2008). EGFR Antagonists in Cancer Treatment. N Engl J Med 358, 1160-1174

David SE, Douglas EW, Dara LA, et al (2017). NonSmall Cell Lung Cancer, Version 5, Clinical Practice Guidelines in Oncology. J National Comprehensive Cancer Network (NCCN) 15, 504-535

Ettinger DS, Akerley W, Bepler G, et al (2010). Non small cell lung cancer clinical practice guidelines in oncology. Natl Compr Cancer Netw 8, 740-801

Falanga A (2009). The incidence and risk of venous thromboembolism associated with cancer and nonsurgical cancer treatment. Cancer Investig 27, 105-
115. Available at https://www.ncbi.nlm.nih.gov/ pubmed/19160098. Accessed September 14, 2018

Greene FL, Page DL, Fleming ID, et al (2002). Cancer Survival Analysis. In: AJJ Cancer Staging handbook, 6th Ed. New York, Springer, p 15-25

Huang L, Fu L (2015). Mechanisms of recistance to EGFR tyrosine kinase inhibitors. Acta Pharmaceutica Sinica B 5, 390-401. Available at https://core.ac. uk/download/pdf/ 82702660.pdf. Accessed September 12, 2018

Jemal A, Bray F, Center MM, et al (2003). Global cancer statistics. A Cancer Journal Clinicians 61, 6990

Kosasih, Alvin, Susanto AD, et al (2008). Diagnosis Dan Tatalaksana Kegawatdaruratan Paru Dalam Praktek Sehari-hari, Jakarta, Sagung Seto

Lee AY (2005). Management of thrombosis in cancer: primary prevention and secondary prophylaxis. $\mathrm{Br} \mathbf{J}$ Haematol 128, p 291-302. Available at https://www.ncbi.nlm.nih.gov/ pubmed/ 15667530. Accessed 09 10, 2018

Mok TS, Wu YL, Thongprasert S, et al (2009). Gefitinib or carboplatinpaclitaxel in pulmonary Adenokarsinoma. N Engl J Med 361, p 947-57

Nordstrom M, Lindblad B, Bergqvist D, et al (1992). A prospective study of the incidence of deep-vein thrombosis within a defined urban population. J Intern Med 232(2), p 155-160. Availabe from https://www.ncbi.nlm.nih.gov/pubmed/1506812.

Accessed 09 14, 2018

Parkin DM, Bray F, Ferlay J, et al (2002). Global cancer statistics 2002. A Cancer Journal Clinicians 55(2), p 74-108

Rosell R, Moran T, Queralt C, et al (2009). Screening for epidermal growth factor receptor mutations in lung cancer. N Engl J Med 361, 958-67

Sequist LV, Waltman BA, Dias-Santagata D, et al (2011). Genotypic and histological evolution of lung cancers acquiring recistance to EGFR inhibitors. Sci Transl Med 3, 75ra26

Shinagare AB, Guo M, Hatabu H, et al (2011). Incidence of pulmonary embolism in oncologic outpatients at a tertiary cancer center. Cancer $117, \mathrm{p}$ 3860-6. Available at https://www.ncbi.nlm.nih.gov/ pmc/articles/PMC3131455/. Accessed September 11, 2018

Socinski MA, Villaruz LC, Ross J (2016). Understanding mechanisms of recistance in the epithelial growth factor receptor in non-small cell lung cancer and the role of biopsy at progression. Oncologist 21, 1-9

Sorensen HT, Mellemkjaer L, Olsen JH, et al (2000). Prognosis of cancers associated with venous thromboembolism. N Engl J Med 343, 1846-50. Available at https://www.ncbi. nlm.nih.gov/pubmed/11117976. Accessed September 13, 2018 
Thomas A, D'Amico MD, Malcolm M, et al (2004). EGF receptor gene mutation are common in lung cancer from "never smokers" and are associated with sensitivity of tumors to gefinitib and erlotinib.Proceedings of the National Academy of Science 101, 13306-11

WHO (2004). Histological of the tumor of the lung. In: Tumor of the lung-WHO classification

Yang P, Cerhan JR, Vierkan RA, et al (2002). Adenokarsinoma of the lung is strongly associated with cigarette smoking: further evidence from a prospective study of women. American Journal of Epidemiology 156, 1114-1122

Yun C, Mengwasser KE, Toms A V, et al (2008). The T790M mutation in EGFR kinase causes drug recistance by increasing the affinity for ATP. Proc Natl Acad Sci USA 105, 2070-2075. Available at https://www.ncbi.nlm.nih.gov/pubmed/18227510.

Accessed September 11, 2018 